\title{
Las películas sobre el maquis español: de la historia oficial a la memoria histórica
}

\author{
Josefina Martínez Álvarez \\ Universidad Nacional de Educación a Distancia \\ jmartinez@geo.uned.es
}

Recibido: $28 / 01 / 2012$

Aceptado: 05/07/2012

\section{RESUMEN}

El cine, como documento y como parte de la historia, brinda un enfoque específico sobre los maquis que abarca desde los años cincuenta hasta la actualidad, y el estudio de los expedientes de Censura durante el franquismo ilustra cómo fueron los caminos seguidos por los proyectos sobre los guerrilleros hasta su consecución. En este artículo se aborda la evolución del estereotipo según las circunstancias políticas acorde con la ideología predominante: en el franquismo se parte de una imagen de individuos equivocados y arrepentidos, pasando por bandoleros y asesinos. Ya en la Transición, los maquis se tornan en algunos casos en supervivientes, e incluso en héroes. La mayoría de los directores cinematográficos, bien de manera oblicua para traspasar las normas censoras o bien de forma diáfana ya en la Democracia, han reivindicado para la historia la lucha de la guerrilla antifranquista.

Palabras clave: Cine, Guerrilla antifraquista, Franquismo, Maquis, Censura cinematográfica, Memoria Histórica.

\section{Movies about the Spanish "Maquis": from the Official History to the Historical Memory}

\begin{abstract}
The cinema, both as documental source and as a part of History, provides a specific point of view on the "Maquis" subject. The present manuscript focus on the evolution of this character since the fifties until nowadays, which has changed accordingly to the different political landscapes that had gone through Spain: during early Franquism their image starts as wrong and regretted individuals that yields to partizans and assasins; in the late Franquism their image achieved a reasonable recognisement. The study of the Censorship files during this period illustrates how the paths followed by the projects about these guerrilla were. During the Transition, the Maquis turn up sometimes into survivals, even in heroes. Most directors have claim a place in history for the fight of this antifranquism guerrilla, first biased to pass through the franquism censorship and lately in the Democracy in a plain way.
\end{abstract}

Key words: Cinema, Anti-Franquism Guerrilla Warfare, Franquism, Maquis, Cinematographic Censore, Historical memory.

Sumario: Introducción. 1. La creación de un estereotipo en los inicios del franquismo. 2. Asesinos, saboteadores y traidores. 3. Una mirada exterior y el giro tardofranquista. 4. De la delincuencia al mito. 5. Utopía y ucronía durante el primer socialismo. 6. La desmitificación del mito. 7. Conclusiones. 


\section{Introducción}

Para muchos, la guerra civil no terminó en abril de 1939. Desde 1936, según avanzaban las columnas franquistas, bolsas de hombres leales a la República se guarecían en las serranías para evitar la represión. Pronto se convirtieron en los huidos y, al correr del tiempo, en el maquis ${ }^{1}$. Tras el conflicto, el miedo a las represalias y la creencia de que en breve Franco caería, hizo que varios miles de españoles permanecieran escondidos en los montes, al otro lado de los Pirineos y en las grandes ciudades, dispuestos a terminar con el régimen opresor ${ }^{2}$.

La despolitización impuesta a la sociedad por una dictadura de partido único, la fragmentación de las fuerzas políticas antifranquistas así como la dificultad de encontrar un apoyo popular, impidieron al maquis alcanzar sus objetivos. Tampoco la evolución política internacional les favoreció: si en 1944, a la vista de una victoria aliada inminente, el fin de Franco no llegó, menos aún sucedería tras el reconocimiento internacional del Régimen en los 50 y el desmoronamiento de los partidos comunistas occidentales. Lentamente, las fuerzas del orden franquistas fueron desarticulando los focos de resistencia hasta que prácticamente, diez años después de terminada la guerra, el maquis había desaparecido. Será, a partir de entonces cuando la sociedad española comience a reconocer a los excluidos. Y el cine, espejo de esta sociedad, posará su mirada en ellos.

Hasta 1975, un cierto número de directores comprometidos con los derrotados, bien ideológica o bien emocionalmente, representaron a los maquis de la manera más abierta que les permitió el Régimen. Entonces, se creó un estereotipo de los vencidos que pervivió prácticamente sin fisuras hasta la muerte del Dictador. Llegada la Transición democrática esta imagen se intentó mudar, pero la amnesia institucional que se impuso sobre el pasado reciente, tampoco les favoreció. Ha tenido que transcurrir casi medio siglo para que la resistencia del maquis haya ocupado un espacio, no muy amplio, en la memoria, un reconocimiento en el que el cine ha jugado un papel importante para su reivindicación.

En este artículo vamos a explorar la visión de la guerrilla antifranquista en la gran pantalla, qué aspectos han primado al trasladar su imagen al lienzo, cómo ha sido definida y qué particularidades han pervivido de aquellos que entablaron una larga batalla librada hasta la extenuación de sus combatientes.

\section{La creación de un estereotipo en los inicios del franquismo}

En el cine español, hasta principios de los 50, había prevalecido la retórica de las dos Españas a la hora de mostrar la imagen de unos vencedores en lucha a muerte con la anti-España comunista y atea. Contra los restos de ésta segunda se había dictado

\footnotetext{
1 RODRÍGUEZ VELASCO, Hernán: "Las guerrillas en el Ejército Popular de la República (1936-1939)”, Cuadernos de Historia Contemporánea, 33 (2011), pp. 235-254.

2 Sobre las diferencias entre huidos y los distintos tipos de maquis véase MORENO GÓMEZ, Francisco: La resistencia armada contra Franco. Tragedia del maquis y la guerrilla, Barcelona, Crítica, 2001.
} 
la ley de Responsabilidades Políticas (13-2-39) y más adelante la de Bandidaje y Terrorismo (18-4-47) que equiparaba los delitos políticos con los de rebelión militar ${ }^{3}$.

El estereotipo del vencido, presentado en las películas de los cuarenta, es en general el del miliciano borracho, cruel, pendenciero y revanchista a quien hay que destruir. Así aparece en Raza (José Luis Sáenz de Heredia, 1941) o Rojo y Negro (Carlos Arévalo, 1942), por poner un ejemplo. Pero a mediados de los cincuenta, la nueva política internacional del Régimen y su apertura al mundo, decidió recurrir a la industria cinematográfica como una de sus bazas para manifestar la renovada imagen del franquismo, de la que se ocupará, a partir de 1951, el recién creado Ministerio de Información y Turismo ${ }^{4}$. En este contexto se abrirá un espacio dedicado a mostrar cierta magnanimidad con los vencidos, tal y como se aprecia en las cuatro películas alusivas al maquis producidas a partir de entonces: Dos caminos (1953), El cerco (1955), La ciudad perdida (1955) y Torrepartida (1956).

Tampoco resulta ajeno el que entre las filas de aperturistas, falangistas desencantados, jóvenes y algunos católicos se propusiera un giro hacia el diálogo y la tolerancia. Con cierta profusión, en ensayos políticos y en la prensa, comenzaron a utilizarse términos como reconciliación y convivencia humana ${ }^{5}$. A ello se suma la nueva postura tanto del PCE como del PSOE que desde el exilio, en 1948, anunciaron la disolución de la guerrilla y el abandono de la lucha armada, muy en la línea de la política europea del momento ${ }^{6}$. Aún así, algunos anarquistas mantuvieron el enfrentamiento en las ciudades, y en el monte continuaron escondidos aquellos que se negaron a claudicar. No hay que obviar el enconado cerco puesto por las fuerzas de orden público que ahogaron a los rebeldes ${ }^{7}$ al atenazar a sus "simpatizantes y abastecedores", forzando a los huidos a robar a campesinos sin filiación política que no tuvieron reparo en delatarlos. ${ }^{8}$

En línea con aquella nueva política, Arturo Ruiz Castillo (1910-1994) será el primer cineasta español que encare la figura de los maquis. En 1932 había participado en la compañía estatal de teatro universitario La Barraca. Asimismo había colaborado en las Misiones Pedagógicas filmando varios documentales experimentales; en 1935 ya había rodado catorce.

3 ARÓSTEGUI, Julio y MARCO, Jorge (eds.): El último frente. La resistencia armada antifranquista en España, 1939-1952. Madrid, La Catarata, 2008. p. 29.

4 MARTÍNEZ, Josefina: "El cine de los Cincuenta: una década de contradicciones". En Abdón MATEOS, (ed.): La España de los Cincuenta, Madrid, Eneida, 2008, pp. 337-368.

5 AGUILAR FERNÁNDEZ, Paloma: Memoria y olvido de la guerra civil española, Madrid, Alianza Editorial, 1996, p. 104 y ss.

6 En mayo de 1947 los ministros comunistas fueron expulsados tanto del gobierno francés como del italiano y los mandatarios occidentales abrieron gustosamente sus arcas para llenarlas con los dólares repartidos por el Plan Marshall. JUDT, Tony: Postguerra. Una historia de Europa desde 1945, Madrid, Taurus, 2005, p. 208.

7 El 29 de mayo de 1955, Camilo Alonso Vega, en su discurso de despedida como director general de la Guardia Civil, ofrecía la cifra de 5.548 "bandoleros suprimidos" así como los cerca de 20.000 enlaces detenidos durante los casi doce años de su mandato. AGUADO, Francisco: El maquis en España, Madrid, San Martín, 1975, p. 19. MORENO GÓMEZ, Francisco: La resistencia ..., p. 690, considera que existía un $26 \%$ más de guerrilleros que los recogidos en el cómputo oficial.

8 PITT-RIVERS, Julián: Un pueblo de la sierra: Grazalema, Madrid, Alianza Editorial, 1989, pp. 181183. 
Durante la guerra, Ruiz Castillo empuñó la cámara para recoger las acciones bélicas de la División 46 de El Campesino. En el frente rueda diferentes reportajes para el noticiario cinematográfico España al día, para la Subsecretaría de Propaganda y para la sección de cine de la Alianza de Intelectuales Antifascistas para la Defensa de la Cultura. Entre sus filmaciones destacan títulos como Un año de guerra, Guerra en el campo, iSalvad la cosecha!, Cirugía y recuperación, Guerra en la nieve y Prisioneros en Valencia ${ }^{9}$.

Terminada la guerra, no fue tanto la represión política ${ }^{10}$ como la penuria económica lo que ralentizó su carrera como cineasta. Aún así, en 1947 su producción superaba los cincuenta cortometrajes y había filmado su primer largometraje, Las inquietudes de Santi Andía. A continuación rodó La manigua sin Dios (1949) y El santuario no se rinde (1950) -loas al Ejército y a la Guardia Civil respectivamente-, que le alejaron de cualquier sospecha como realizador de ideas comunistas o revolucionarias. De este modo pudo acometer el guión de Dos caminos, film que explora las consecuencias de la guerra para los soldados republicanos que, junto a $E l$ santuario no se rinde, formará parte del nuevo entramado propagandístico del Régimen marcado por "la consigna de apaciguamiento y reconciliación entre vencedores y vencidos" ${ }^{11}$ donde los "rojos" comienzan a presentar una cierta dignidad ${ }^{12}$.

En este largometraje, estrenado el 1 de febrero de 1954, Ruiz Castillo reúne a dos amigos combatientes republicanos que, en 1939 al cruzar la frontera de Le Perthous, se separan. Antonio (Miguel Picazo), regresa para ejercer, no sin problemas, como médico cerca de Gerona, y Miguel (Rubén Rojo) continúa su éxodo por Francia para retornar con las partidas guerrilleras de 1945. Al ser herido, Miguel ordena a sus hombres que secuestren a Antonio. Y durante una larga noche, al abrigo de una cueva, ambos repasan sus vidas tras su alejamiento. Miguel relata su ingreso en el campo de concentración de Argelés. Allí, casi a su lado, ve como muere un poeta, solo, recitando A orillas del Duero. Aunque no se ajuste a la realidad, Ruiz Castillo utilizó la nostalgia evocada por Machado, homenajeándolo en su destierro, para convertir su verso en el desiderátum del guerrillero: volver.

El arrepentimiento del miliciano traza su discurso de esa noche. Su obsesionante retorno va a estar empedrado de equívocos: "Y de nuevo me vi por un camino que no iba a ninguna parte". A través de flash back narra su ingreso en el maquis francés, su enfrentamiento con los brutales jefes comunistas, los sabotajes a los alemanes y la lucha por el poder entre los comunistas marselleses. Por el contrario Antonio, que ha sufrido el desprecio incluso de los más pobres -representantes de la ignorancia y

9 AMO, Alfonso del: Catálogo general del cine de la guerra civil, Madrid, Cátedra, 1996. Ruiz Castillo nunca firmó sus cortometrajes pues temía por la vida de sus padres, huidos de La Granja (Segovia) a Valladolid en julio de 1936. Declaraciones hechas a la autora. 21-1-1991.

10 Sólo pasó algunas noches en la Dirección General de Seguridad donde sufrió varios interrogatorios. Declaraciones hechas a la autora. 21-1-1991.

11 GUBERN, Román: 1936-1939: La Guerra de España en la Pantalla. De la Propaganda a la Historia, Madrid, Filmoteca Española, 1986, p. 112.

12 MARTÍNEZ, Josefina: "La imagen del ejército español en el cine durante el franquismo", en Fernando PUELL DE LA VILLA y Sonia ALDA MEJÍAS (coord.): Los ejércitos del franquismo (1939-1975). Madrid, Instituto Universitario General Gutiérrez Mellado-UNED, 2010, pp. 545-572. 
la superstición que le niegan incluso el perdón-, argumenta su decisión de quedarse: "Pasara lo que pasara, a pesar del miedo y la culpabilidad".

Ya al amanecer, cuando se escuchan los disparos de la Guardia Civil, Miguel intuye que ha sido traicionado y actúa a la desesperada. Antonio le manifiesta su lealtad: "No voy a entregarte, aún estás a tiempo de huir a Francia". Pero Miguel ya ha tomado su decisión: "He venido para quedarme en esta tierra de una forma u otra" y, tras sus palabras, sale del abrigo y es abatido. En los brazos de su camarada murmura: "Ha sido una locura.... La tierra.... Volver". Entre tanto, un oficial del Servicio de Información franquista, encastrado entre los hombres de Miguel, se da a conocer a los asaltantes.

No resultó sencillo concluir este film. El guión fue presentado a la Junta de Censura $^{13}$ el 20 de octubre de 1952 siendo rechazado por "la confusión y flojedad del texto" "14: los censores exigían "un argumento intenso [para los personajes] que se desarrolle paralelamente al histórico político con el que estamos de acuerdo" 15 , y eliminar la posible tibieza religiosa de Antonio el médico ${ }^{16}$. Asimismo consideraban que el tema era de poca actualidad y bastante vulgar pues "las luchas de la vida de Pascual [nombre de Miguel en el primer guión] son las de muchos rojos, que han pasado por las mismas vicisitudes de los protagonistas". Por último, sugerían diferentes mejoras como que "ajustándose a la realidad, se recogiese que la partida de Pascual, lo mismo que otras partidas análogas infiltradas por los Pirineos, viva sobre el terreno, del bandidaje y que son por tanto perseguidos no solo por atentar contra el orden público y la autoridad sino por robos y saqueos y demás fechorías que caen de lleno dentro de la delincuencia común." En una palabra, que el film provocara un desprecio implícito hacia los maquis.

Sin recoger dichas sugerencias, aunque presentadas las oportunas modificaciones, el guión fue aprobado en enero de 1953. Esta segunda versión agradó más a los censores pues incidía en que "los rojos españoles en tierras de Francia [eran] explotados por el partido comunista" así como "un realismo muy aleccionador y verosímil que es aún oportuno". Además, se elogiaban sus valores didácticos: "Vemos con agrado que sea recuerdo de muchos y lección de los que desearían volver." ${ }^{17}$ Por descontado, resultaba preceptivo suprimir aquello que atentase contra la moral.

13 El decreto del 21-3-52 incluía a la Junta de Clasificación y Censura de Películas Cinematográficas en el Instituto de Orientación Cinematográfica dependiente del nuevo ministerio. Contaba con dos secciones: una dedicada a la labor censora y la otra, con carácter económico, competente para clasificar las películas según su calidad y determinar las ayudas a la produc-ción. Véase VALLÉS COPEIRO DEL VILLAR, Antonio: Historia de la política de fomento en el cine español, Valencia, Filmoteca de la Generalitat Valenciana, 1992.

14 Archivo General de la Administración, Sección Cultura, a partir de ahora AGA, SC, 36/4733.

15 Ibidem.

16 Ibídem. "En la página 29 (...) deberá de modificarse la frase de modo que quede claro y concreto que se refiere a sus desengaños políticos [no religiosos]." Además -aconsejaba el lector eclesiástico, Antonio Garau- "en la página 55-56 cortar el beso antes de cortar el plano, a fin de evitar sugerencias que enturbien una película limpia desde el punto de vista moral."

17 Ibídem. Se insiste en la supresión de los siguientes planos: Marcelle medio desnuda (p. 54); en bici enseñando las piernas provocativamente que consigue una reacción sexual de los presos (p. 73). Para evitar equívocos, conviene que Marcelle no pase la noche en la misma habitación de Miguel (p. 87) y cuidar la escena en que Marcelle y Miguel están tumbados en la hierba (pp.108-109). 
Antes de su estreno, la película se presentó en el festival de Cine de Málaga, obteniendo el primer premio, y en el de la Merced de Barcelona, donde la crítica resaltó la dificultad de "sintetizar el drama de los españoles que equivocados o engañados atravesaron la frontera en enero de 1939 (...) y, frente a ellos, la verdad de quienes se quedaron" ${ }^{18}$. A la vista de su buena acogida, el Sindicato Nacional del Espectáculo la designó para el certamen de San Sebastián, lo que estuvo a punto de provocar la retirada de la delegación francesa por la imagen distorsionada que, según ésta, se ofrecía de la resistencia y el trato dado a los republicanos españoles ${ }^{19}$.

Sin embargo, la crítica de la revista cinematográfica más popular del momento, Primer Plano, no resultó tan elogiosa. La temática del film desagradó a su redactor jefe, el camisa vieja José Luis Gómez Tello, que en su sección "La crítica es libre" subrayaba: "No está muy claro el propósito que se ha seguido con este argumento (...) Ante tipos como Miguel no cabe objetividad. Y no cabe tampoco el imaginarle ni simpático ni agradable sobre todo cuando el contraste con otros personajes -como el pregonero, la mujer enlutada o el otro médico ${ }^{20}$ - resulta, por lo menos hiriente." 21

El guión de Dos caminos, escrito por Clemente Pamplona ${ }^{22}$ y José Antonio Pérez Torreblanca ${ }^{23}$, conforma el primer estereotipo del maquis acorde con la desvalorización moral del enemigo que se lanza desde el inicio mismo de la contienda ${ }^{24}$ : un hombre acorralado, arrepentido de sus errores, sin adscripción política, rebelde, agreste, ciego frente a la derrota y, tan embargado por la nostalgia, que prefiere morir. Por otra parte, la película encerraba una feroz enseñanza moral: se admitía el arrepentimiento pero la culpa exigía un castigo, las equivocaciones había que pagarlas con la muerte, en la línea con la ideología del Régimen respecto a los desafectos.

Otro elemento que se vislumbra en esta primera cinta es la traición, bien por la incursión del enemigo en las filas, bien por parte de los propios compañeros. La crueldad de los mandos comunistas será otro rasgo constante en la construcción del discurso elaborado para el gran público, relacionado con los nuevos intereses internacionales abiertos ante la Guerra Fría. La necesidad del Régimen de alinearse con los norteamericanos en contra del bolchevismo crea una retórica permanente que se plasma en los filmes bélicos del periodo donde, no son los soldados republicanos los más perversos sino, específicamente, los comunistas extranjeros ${ }^{25}$.

Esta traición de propios y extraños será asimismo el leitmotiv de El cerco, dirigida por Miguel Iglesias Bonns (1915) estrenada el 1 de septiembre de 1955. Estaba inspirada en la novela Brigada criminal, escrita por el jefe de la misma de Barcelona,

18 La Vanguardia, 2-10-53.

19 TUDARI, José Luis: San Sebastián, un festival una historia (1953-1966), San Sebastián, Filmoteca Vasca, 1989, p. 20.

20 En la película atacan verbalmente a Antonio por haber sido republicano.

21 Primer Plano, 7-2-54.

22 Clemente Pamplona (1917-2001), durante la guerra civil fundó el diario Lucha en Teruel. En 1945 ingresó en Radio Nacional.

23 José Antonio Pérez Torreblanca (1911-1970), Además de magistrado de la Audiencia Territorial de Madrid, en 1941 fundó en Valencia el diario Jornada. Fue el primer director de Televisión Española.

24 Sobre la construcción de la imagen del enemigo véase SEVILLANO CALERO, Francisco: Rojos. La representación del enemigo en la guerra civil, Madrid, Alianza Editorial, 2007.

25 Ejemplos de ello son Ronda española (Ladislao Vajda, 1951) o Murió hace quince años (Rafael Gil, 1954). 
que recogía diversos hechos delictivos vividos por el autor y las acciones del grupo de Facerías ${ }^{26}$, presentado entonces como un criminal común ${ }^{27}$. Al prohibir la censura cualquier referente político, la sinopsis enviada por la productora a la Comisión destacaba sobre todo el sentido moral de la cinta: "El dinero robado a nadie aprovecha siendo las más de las veces causa de tragedia" 28 .

A la vanguardia del cine negro barcelonés, que se inicia prácticamente con esta película ${ }^{29}$, El cerco es sobre todo un drama policiaco, donde unos atracadores asaltan una fábrica y, siguiendo la pista de uno de ellos herido, la policía acorrala al jefe de la banda, después de que éste haya matado a sus compañeros. La censura la aprobó al incluir ciertos valores morales: "Justicia final con expiación del delincuente" ${ }^{30}$. Una vez filmada, a la Comisión de Clasificación no le agradó en demasía por tratarse de un "guión policiaco sin ninguna originalidad en su desarrollo y desde luego sin el menor interés, (...) tema vulgar, exceso de escenas de crímenes y violencia, y truculencia." ${ }^{31}$. La censura limitaba tanto la iniciativa de los directores, que Iglesias Bonns tuvo que transformar las acciones del anarquista barcelonés en las de un criminal común para poder rodar el film. Cinco años después este director incidirá en la figura de los guerrilleros perfilando algo más a los protagonistas en Carta a una mujer.

También la traición y la nostalgia fueron el desencadenante de la tragedia de Rafa (Fausto Tozzi), el protagonista de La ciudad perdida. Dirigida por la actriz Margarita Alexandre (1923) y el guionista Rafael Torrecilla (1927) quienes acababan de estrenar un documental titulado Cristo. La ciudad perdida estaba basada en la novela homónima de Mercedes Fórmica. En ella se narra la última jornada en Madrid de un "terrorista acorralado" -indicaba la crítica de $A B C^{32}$, un "hombre acorralado" rezaba el cartel del estreno en Barcelona- ${ }^{33}$ que regresa de Francia con una misión política. Nada más llegar, por una delación, el grupo es alcanzado por la policía y, tras un tiroteo, al huir, Rafa pierde su documentación. Entonces decide buscar al enlace quien, al verse en peligro, le recrimina su desobediencia: “No se le había ordenado desistir?" -le espeta- "Sí, pero el partido no puede abandonarnos" -responde Rafa-“¡Ud. es quien ha abandonado al partido al desobedecer órdenes, Ud. es el traidor!".

Abrumado por las dudas y la frustración, impregnado de nostalgia, Rafa deambula por Madrid, rememorando su juventud, su afiliación al Partido, la renuncia a sus estudios y el enfrentamiento con su padre: “¡Eres un rojo!" -le acusa su progenitor"¿Rojo, porque creo en una justicia mejor, en la paz de todos los hombres?" -responde Rafa-, secuencias que en clave alegórica encierran la resistencia popular durante y después de la guerra civil ${ }^{34}$.

26 José Luis Facerías (1920-1957), perteneciente a las Juventudes Libertarias, fue jefe de una partida barcelonesa. Véase SÁNCHEZ AGUSTİ, Ferran: El Maquis anarquista. De Toulouse a Barcelona por los Pirineos, Lleida, Milenio, 2005.

27 COMAS, Ángel: Miguel Iglesias Bonns: 'cult movies' y cine de género, Valls, Cossetània, 2003, p. 56.

28 AGA, SC, 36/3515.

29 MEDINA, Elena: Cine negro y policiaco español de los años cincuenta, Barcelona, Laertes, 2000, p. 28.

30 AGA, SC, 36/4756.

31 Ibídem.

$32 A B C, 1-10-55$.

33 La Vanguardia, 20-10-55.

34 CAMINO, Mercedes: "El melodrama fascista y la memoria cinematográfica del maquis español", Imagofagia, 4 (2011), p. 9. 
Desolado, secuestra a una dama -María- para despistar a la policía. Escondidos en el vagón de una estación abandonada, ambos pasan la noche y van intimando, hasta que él declara: "Este es el fin de una vida equivocada, de un idealismo basado en un crimen." Al oírse los coches de la policía, María, a quien se le han caído los estereotipos sobre los rojos, le urge: "¡Tiene que salvarse, entréguese!", pero Rafa reconoce lo inevitable: "Es inútil, mi destino es luchar..." Saliendo hacia la vía, es acribillado a balazos.

Realizada en coproducción con Italia, los directores decidieron comenzar el rodaje sin esperar a la resolución sobre el guión de la Junta ${ }^{35}$. Y ésta fue contundente al presentarse ya rodado: había que modificar los diálogos y el final. El presidente de la Comisión, Alfredo Timermans, exigía que "con un nuevo doblaje se quite al protagonista rojo su carácter simpático y de héroe y [que] desaparezca el enamoramiento de la joven, y que ésta le recrimine su conducta y condene" ${ }^{36}$. El informe apostillaba sobre la imposibilidad de "autorizar este cinta en la que aparece exaltada la figura de un rojo español que confiesa haber asesinado a numerosas personas" ${ }^{37}$. Fue imprescindible suprimir la familiaridad pues, como su directora años después declaraba: "De ninguna manera una señora podía dar el tú a un rojo (...) Los protagonistas conversaban y sus diálogos no tenían nada que ver con los rostros de los actores." 38

Con estos cambios fue estrenada el 1 de octubre de 1955 en el Palacio de la Música de Madrid. A la crítica tampoco le convenció, aunque se le reconociera la sobriedad y el sentido de la composición, la evolución psicológica de los personajes que, según la crítica, había sido "tan bien expuesta en la novela, [y que en el film] dejaba mucho que desear" 39 . A pesar de los cortes y modificaciones del celo censor, la película lograba inclinar al espectador hacia la compasión con el protagonista solitario, abandonado, perdido, para quien la muerte era la única salida.

Si hasta aquí el amor había permanecido en segundo plano, éste será el motivo que engendre la tragedia en Torrepartida, la última cinta de la década. La acción se desarrolla en la serranía de Teruel ${ }^{40}$, donde dos hermanos, Ramón (Miguel Armet) -alcalde del pueblo que da el nombre al film- y Manuel (Germán Cobos) -integrante de una partida- aman a la misma joven, María (Nicole Gamma). Torrepartida es un claro ejemplo de cómo el melodrama fascista politiza la relación entre el dominio público y el doméstico: la familia deviene en un microcosmos donde se dirimen los asuntos universales ${ }^{41}$. Así, la alegoría de la guerra civil como un enfrentamiento entre

35 AGA, SC, 36/4750. El 9-9-54 se presentó el guión a censura y el 20-9-54, la Dirección General proponía la concesión del permiso teniendo en cuenta las objeciones al guión. Los directores iniciaron el rodaje tres días después. En diciembre se solicitó el permiso de coproducción, cuando prácticamente se finalizaba el rodaje, sin contemplarse las consideraciones de la Comisión sobre el texto.

36 Ibídem. A la vez Timermans reprendía a la Dirección General de Cinematografía por haber concedido un permiso de rodaje sin la previa autorización del guión.

37 Ibídem. Informe de la Junta de Clasificación y Censura, 16-3-55.

38 VARELA, María Camí: "Una cineasta española en la revolución cubana”, El viejo topo, 231 (2007), p. 102.

$39 A B C, 1-10-55$

40 Sobre la guerrilla en esta zona véase YUSTA RODRIGO, Mercedes: La guerra de los vencidos. El maquis en el Maestrazgo turolense, Zaragoza, Diputación Provincial, 1999.

41 KINDER, Marsha: Blood cinema: The reconstruction of national identity in Spain, California, University of California, 1993, p. 72. 
hermanos, alcanza en Torrepartida uno de sus máximos exponentes. El rótulo inicial de la cinta ya lo aclara: "La desunión entre hermanos, fomentada por pasiones e intereses bastardos, conduce inexorablemente a la ruina y a la muerte."

El guión había sido premiado en el concurso del Sindicato de 1954 por su exaltación a "aquellos que lucharon por el exterminio de las partidas de bandoleros." 42 Su director Pedro Lazaga (1918-1970), combatiente del ejército republicano, había luchado en el frente de Aragón. Al concluir la contienda, juzgado y encarcelado, había conseguido la libertad al alistarse en la División Azul ${ }^{43}$. A su vuelta simultanea su actividad en el Sindicato de la Pesca con su afición por el cine ${ }^{44}$. Como Ruiz Castillo, afronta el tema del maquis tras un drama de gran éxito, La patrulla, que narra los avatares de cuatro soldados franquistas al separarse terminada la guerra civil.

Torrepartida se acerca más al western o al cine de aventuras que al drama político. La brutalidad, el egoísmo, la avaricia e incluso un cierto viso de homosexualidad del jefe de la partida, Rafael (Adolfo Marsillach) ${ }^{45}$, harán comprender a Manuel, después de que aquél secuestre a María, su error. Manuel es presentado como un hombre de buen corazón pero equivocado.

En esta cinta se abunda en la perversidad de los jefes guerrilleros: Rafael es un facineroso autócrata y sin escrúpulos: "¡Yo soy quien manda aquí, inútiles!" -grita tras abofetear a Manuel-, hasta el punto de hacerle dudar del amor y de la lealtad de María, que incluso había ocultado a los hombres tras un atraco. El sadismo de Rafael alcanza el límite cuando asesina al rehén, hijo del capitán de la Guardia Civil, colocando una bomba debajo de su cuerpo.

La cinta no obtuvo demasiado éxito. Estrenada en noviembre de 1956, sus productores solicitaron a la Junta de Clasificación la revisión para que fuese incluida en la categoría de Interés Nacional, por "contribuir a deshacer parte de la leyenda negra antiespañola fomentada por los enemigos de siempre de nuestra verdad actual" ${ }^{46}$. La retórica propagandística del Régimen se traslucía en el argumento esgrimido por los productores que abundaba en la cultura del miedo ${ }^{47}$. Al ser denegada, se insistió apelando en este caso a criterios económicos, para conseguir "la amortización justa del capital empleado", siendo de nuevo rechazada. ${ }^{48}$ Para la comisión no había causa, a pesar de que el "buen propósito es evidente, lo mismo que la nobleza del tema, pero no así el modo de desenvolvimiento ni el resultado obtenido." 49

A lo largo de estas cuatro primeras cintas quedan, pues, perfilados los rasgos fundamentales de los guerrilleros según el ideario franquista, cuando prácticamente el

42 AGA, SC, 26/4761. Informe del lector Manuel Nolla Rubio.

43 ALEGRE, Sergio: El cine cambia la Historia. Las imágenes de la División Azul, Barcelona, PPU, 1994, p. 298.

44 Era uno de los críticos del cineclub del Círculo de Escritores Cinematográficos.

45 HEREDERO, Carlos F.: "Historias de maquis en el cine español. Entre el arrepentimiento y la reivindicación”, Cuadernos de la Academia, 6 (1999), pp. 215-232.

46 AGA, SC, 36/3563. Instancia de Santos Alcocer al director general de Cinematografía y Teatro, 21-756.

47 Sobre la representación visual del terror rojo véase BERTHIER, Nancy y SÁNCHEZ-BIOSCA, Vicente (eds.): Retóricas del miedo. Imágenes de la guerra civil española, Madrid, Casa de Velázquez, 2012.

48 AGA, SC, 36/3563. Instancia de Santos Alcocer al director general de Cinematografía y Teatro, 1-1156. La Junta desestimó la recalificación.

49 Ibídem. Informe de Alberto Reig en el expediente de recalificación, 3-8-56. 
maquis ya había desaparecido: la nostalgia, la traición, la crueldad de los mandos y el arrepentimiento definían sus personalidades. Entretanto en el exilio, la CNT decretaba en 1951 el fin de la lucha armada ${ }^{50}$ y en junio de 1956 el Comité Central del PCE publicaba un manifiesto sobre la Política de Reconciliación Nacional ${ }^{51}$.

\section{Asesinos, saboteadores y traidores}

$\mathrm{Al}$ inicio de los sesenta el franquismo se hallaba plenamente asentado en el ámbito internacional; la implantación de las medidas liberalizadoras de 1959, que finalizaron el período de la autarquía, permitieron un desarrollo de la economía nacional. En este marco, el fin definitivo de la guerrilla aparecerá como un triunfo más del franquismo: no habrá lugar para ellos en el ideal estado-nación.

Durante esta década tres fueron las películas que contemplaron la figura de los maquis: La paz empieza nunca (1960), Carta a una mujer (1963) y A tiro limpio (1963). Además de abundar en la traición y la violencia, el cine mostró con toda crudeza sus actividades delictivas. Más allá de escrutar sus motivaciones, los filmes inciden en criminalizar sus acciones: la extorsión, el robo, el secuestro y el asesinato. La idea de lucha política prácticamente desaparece y los maquis pasan a ser retratados como meros delincuentes.

Estos filmes también beben de las nuevas corrientes cinematográficas, sobre todo de la nouvelle vague francesa: adquieren un mayor realismo y violencia, las peleas son más duras y largas, los disparos se producen a bocajarro, los hombres muestran una sádica misoginia. Por su parte, el Régimen ya no transige con los que están fuera del sistema, las fuerzas del orden atacan sin piedad a la hora de reprimir la delincuencia. Pero, a pesar de su violencia, las películas son utilizadas por los directores para denunciar la doble moral burguesa, alienada, imbuida de materialismo y ajena a la realidad circundante.

La primera película que abordó el tema de los maquis, otorgándoles un papel antagonista, fue La paz empieza nunca, basada en la novela homónima del periodista Emilio Romero (1917-2003) ${ }^{52}$, galardonada con el premio Planeta de 1957, y dirigida por el argentino León Klimosvky (1906-1996). El héroe es Juan López (Adolfo Marsillach) un apacible falangista que "quería una nación unida, una justicia social y una patria libre" -tal y como declara una voz en off al principio de la cinta-. Convencido por Mencía (Jesús Puente), antiguo camarada que ocupa un oscuro cargo político, es reclutado para infiltrarse en las partidas para reunirlas y desarticularlas. La tesis de Mencía es contundente: "Pertenecemos a un grupo de españoles a los que

50 HERRERÍN LÓPEZ, Ángel: La CNT durante el franquismo: clandestinidad y exilio (1939-1975), Madrid, siglo XXI, 2004, pp. 99-113.

51 VVAA: Historia del Partido Comunista de España, Paris, Éditions Sociales, 1960, p. 257.

52 En 1945 fue designado jefe de la Sección de Prensa Nacional en la Dirección General de Prensa y poco después asumió la jefatura de Orientación Política de la Prensa Española. En 1946 ingresó en el diario vespertino madrileño Pueblo, el cual dirigió durante 22 años a partir de 1952, convirtiéndolo en uno de los tres más significativos de la época. Fue director de la Escuela Oficial de Periodismo de Madrid y gestionó la creación de la Facultad de Ciencias de la Información. 
nos ha tocado renunciar a nuestra paz." Comprendido el mensaje, López acepta la misión: "No debe haber más luchas entre los españoles."

Poco a poco López logra la confianza de los guerrilleros. Les expone argumentos tácticos: "Unas partidas armadas y unidas, disciplinadas, darían la impresión al mundo de que la guerra civil no ha terminado... eso podría justificar incluso una intervención en España", a lo que responden con un displicente egoísmo quienes, al parecer, sólo desean salvar el pellejo. Además de letales -el enlace con Toulouse no duda en liquidar a una chica de alterne con la que tiene relaciones, a la sazón antigua novia de López-, son violentos y ateos: uno de los jefes, por gusto, ametralla a un sacerdote mientras oficia. Ataviados con los peores atributos de la humanidad, al espectador no le queda otra opción que asentir ante la necesaria justicia para liquidar semejante lacra. López consigue sus objetivos, reúne a las partidas para recoger un alijo de armas y la Guardia Civil da buena cuenta de ellos. Un epílogo anacrónico y demagógico culmina la película: "La historia de España la estamos haciendo todos los españoles: los que ganamos y los que perdieron nuestra guerra. Y para hacer cosas que dejen en buen lugar a nuestro pueblo, ahora que queremos ir todos hacia arriba, la paz empieza nunca."

El proyecto original de Klimovsky distaba bastante del resultado final. Pretendía denunciar el fanatismo de la obra de Romero pero la Junta de Censura y el propio autor, supervisor del guión, impidieron los reajustes. Hubo de aceptar añadidos, supresiones, cambios y reescritos en los diálogos para poder rodar, pues como señala el dictamen de la Comisión eran necesarios insertos para clarificar "la lucha de aquellos hombres que expusieron sus vidas impulsados por los ideales que en definitiva no son otros que los eternos ideales de España" ${ }^{53}$. Al propio Ministerio del Ejército le resultaba tibia la postura de López y exigió "encuadrar mejor la acción dentro de las circunstancias históricas en que se desarrolló, a fin de que quede más clara ante el público" 54 .

Aún estrenándose en 1960, la película recoge las caducas tesis del "cine de cruzada" de los años cuarenta a las que se unen las del subgénero político propio de la Guerra Fría. Pero, en realidad, la trama es más una alegoría sobre las luchas intestinas entre las "familias del régimen" que acabaron con la hegemonía falangista, al ser sustituida por la de los tecnócratas y la de los ministros opusdeistas artífices del "milagro económico". En este caso el maquis es una excusa para trasladar a la pantalla otro tipo de guerra intestina.

Por la insistencia del productor ante el Ministro, se le concedió la categoría de Interés Nacional ${ }^{55}$, aunque la película no le agradó ni al propio Franco. Tal y como le comentaba a Klimovsky después del pase en El Pardo: "Está bien hecha pero no me gusta" ${ }^{\text {" }}$. La indefinición de López, que parece una marioneta del críptico Mencía, y la falta de convicción del personaje, bien pudieran explicar las reticencias del Caudillo.

53 AGA, SC, 36/4820. El guión tuvo que presentarse dos veces a censura. En la segunda sólo se exige la supresión de los planos en que López aparece disparando contra un guardia civil (p. 190).

54 PÉREZ PERUCHA, Julio (ed.): Antología crítica del cine español 1906-1995, Madrid, Cátedra/ Filmoteca Española, 1997, p. 401.

55 AGA, SC, 36/4820. La Junta negó a la película dicha categoría.

56 PÉREZ PERUCHA, Julio: Antología crítica... p. 401. 
Al año siguiente, 1961, la primera obra teatral de Jaime Salom, El mensaje, inspiró de nuevo a Miguel Iglesias Boons para llevar a la pantalla Carta a una mujer. En este caso, Flora (Emma Penella), quien convive con Augusto (Luis Prendes) ${ }^{57}$, descubre por una misiva anónima que su marido, Carlos, un divisionario al que creía muerto en Rusia, y del que nunca estuvo muy enamorada, pudiera seguir aún vivo. No obstante, quien hace que se tambalee el mundo de la feliz pareja va a ser un resentido y embustero comunista, "El Asturiano" (José Guardiola), tornero de una central eléctrica -que había dirigido el marido de Flora-, y que regresa para sabotearla.

La cinta sacará a la luz los remordimientos, la honestidad, la culpa y la duda de Flora que, a la postre, servirán de ejemplo a "El Asturiano" quien tras recapitular, después de confesarle la verdad a Flora, en el momento de activar la bomba se arrepiente y aborta el sabotaje. Obviamente, sus compañeros le acribillan a balazos. Por primera vez en las películas sobre los maquis las distancias entre los malvados y las gentes de bien se acortan: la interacción provocará cambios trascendentales en los protagonistas.

La falta de conciencia de quienes vienen de Rusia, como en el caso de "El Asturiano", es un juego de niños comparada con los que proceden de Toulouse: "No me interesa la política (...) necesitamos metralletas y tipos de confianza. Un par de golpes que harán historia y a veranear al otro lado de la frontera" declara Martín (Luis Peña) a Román (José Suárez), protagonistas de A tiro limpio, un film de corte policiaco dirigido por Francisco Pérez Dolz, y estrenado el 24 de junio de $1963^{58}$. Toulouse, donde se ubicaba la Junta Española de Liberación, era para las mentes de los gobernantes españoles un peligro mucho más cierto que lo que pudiera venir del lejano telón de acero.

Martín regresa a España y le pide a Román que colabore con él y con Antoine (Joaquín Novales) un jovencito infantiloide formado en "El 16 Rue de Lacordaire, de Toulouse", supuesta ubicación de la escuela de activistas comunistas. Su misión consistía en perpetrar acciones desestabilizadoras contra el Régimen, amén de conseguir un botín. Para ello necesitan de El Picas (Carlos Otero), antiguo atracador que vive retirado en una masía, pero que esconde armas.

Martín es sádico, cruel, misógino y veladamente homosexual (increpa a Antoine por mirar cómo unas chicas juegan al baloncesto). En realidad, ambos aparecen como dos delincuentes sin escrúpulos. Román, por su parte, es un ex-activista amargado y misógino (abofetea a su novia y desprecia a su hermana), además de homófobo (llama marica a Martín en una pelea), que sólo desea salir de la pobreza.

Tras varios atracos, al hacer una inspección rutinaria, la policía descubre a El Picas, quien, al huir es herido y Martín, en lugar de ayudarle, lo ahoga. En venganza, Román ahorcará a Antoine. Mientras son rodeados por la policía, los dos supervivientes se enzarzan en una brutal pelea, en la que Ramón mata a Martín que, a continuación, es abatido por los guardias.

57 AGA, SC, 36/3587. Varios componentes de la Junta protestaron ante el amancebamiento de los protagonistas.

58 En 1996 Jesús Mora rodó otra versión, sin ninguna referencia política, que pondrá el acento en la homosexualidad de los protagonistas. 
A tiro limpio fue estrenada en Barcelona, tres meses después de La paz empieza nunca, el 2 de septiembre de 1963. El argumento, escrito por José $\mathrm{M}^{\mathrm{a}}$ Recarte estaba inspirado, una vez más, en las muertes de los maquis libertarios José Luis Facerías (1957) y Quico Sabaté (1960). La productora, para evitar la prohibición de la Junta de Censura, eliminó todo matiz político, resultando un thriller disociado de la lucha guerrillera: sólo las declaraciones posteriores de los autores permiten ligarlo con la guerrilla ${ }^{59}$.

\section{Una mirada exterior y el giro tardofranquista}

Una producción norteamericana de la Columbia, Llegó el día de la venganza (Behold a Pale Horse $)^{60}$, dirigida por Fred Zinneman en 1964 e interpretada por uno de los grandes de la pantalla, Gregory Peck -quien encarna a un mítico excombatiente achacoso y huraño, Manuel Artíguez-, fue prohibida para su exhibición en España ${ }^{61}$. En ella, Artíguez, instalado en Pau, recibe la visita del hijo de un compañero, quien había muerto por no delatarle a manos del capitán Viñolas (Anthony Quinn), para exigir venganza. Viñolas, que aún espera a Artíguez, le tiende una trampa utilizando la enfermedad de su madre como cebo. Ésta le intenta disuadir a través de un sacerdote (Omar Sharif) para que no cruce la frontera. Finalmente Artíguez acepta voluntariamente el desafío y muere acribillado por los hombres de Viñolas. Llegó el día de la venganza no se estrenará en España hasta 1979, una vez desaparecida la censura ${ }^{62}$. Si el Régimen había impedido a los maquis salir de su papel de delincuentes, no iba a tolerar un personaje heroico protegido por un representante de la Iglesia, y menos si esta imagen la lanzaban al mundo entero los guardianes de Occidente. Pero, por mucho que las autoridades franquistas se opusieran, Llegó el día de la venganza suponía un punto de no retorno en cuanto a la imagen nacional e internacional del maquis.

A lo largo de 1964, entre la multitud de eventos organizados para conmemorar los XXV Años de Paz, la mayor campaña propagandística promovida por el Régimen, se filmaron varios documentales y películas de ficción para legitimar al gobierno. A través de la pantalla se trasmitió a la sociedad española un discurso que exaltaba la prosperidad y que, a la vez, se alejaba de la política y de la retórica belicista. Por fin parecía posible arrumbar esa "paz vigilante" en la que el país había estado inmerso. El cine reflejó este cambio y el ejército republicano dejó de mostrarse como una tropa desarrapada y vencida, para constituir un conjunto de personajes con los que se anhela una tibia reconciliación, soldados también profesionales dignos de reconocimiento. En los momentos postreros del Régimen, las voces disidentes, conciliadoras

59 HEREDERO, Carlos F.: "Historias...”, p. 220. Por su parte, la Junta de Clasificación, definiéndola como una película de gángsters "poco original”, exigió recortar las escenas sexuales. AGA, SC, 36/3984.

60 Basada en la novela Killing a Mouse on Sunday del húngaro-británico Emeric Pressburger, quien se había inspirado en el personaje de Quico Sabaté.

61 El Gobierno español presionó a la Columbia para que no se distribuyera el film y destruyera el negativo. Al no conseguir sus propósitos, castigó a la productora a no distribuir sus películas en el país, ni a través de su sucursal ni de otras distribuidoras. TORRES, M. Augusto: "Estreno de la última película prohibida sobre la guerra civil", El País, 15-5-79.

62 El 11 de noviembre de 1977, el Decreto-Ley 3071 dictaba su fin y el de los permisos de rodaje. 
y aperturistas, cuestionaban la utilidad de una guerra fraticida. Por otra parte, en el ámbito internacional, las protestas antibelicistas crearán un tipo de cine antimilitarista (Hombres contra la guerra, Francesco Rosi, 1970; Johnny cogió su fusil, Dalton Trumbo, 1971; Los visitantes, Elia Kazan, 1972) que también influirán en la visión del maquis durante esos años.

Con estas dos premisas, los tintes trágicos y sin apenas heroísmo de las tramas de ficción en que se plasma el conflicto bélico, rebajan también la intensidad con que se había descrito a los republicanos hasta el momento. Se elabora un nuevo discurso: la guerra comienza a plantearse como una locura colectiva.

Al hilo de este discurso, la imagen del maquis da un giro significativo en las dos primeras películas de los años 70: El espíritu de la colmena (1973) y Pim, pam, pum ¡Fuego! (1975). Sus directores van a resaltar un nuevo aspecto hasta ahora apuntado de manera difusa: los guerrilleros son dignos de apoyo, ayuda e incluso de un amor que puede llevar a la muerte. Ciertamente, en algunas de las cintas anteriores habían contado con la complicidad de sus seres queridos, pero a partir de este momento el afecto se convierte en protagonista. Así se describe con una inusitada sensibilidad poética El espiritu de la colmena, dirigida por Víctor Erice (1940), donde la pequeña Ana (Ana Torrent) mima a un fugitivo herido, le entrega su manzana, le obsequia con la chaqueta de su padre y le ata con delicadeza los zapatos. La acción transcurre a mediados de los cuarenta en un desolado pueblo castellano. Tras la proyección de Frankenstein (James Whaler, 1933), Ana decide explorar el mito, invocar al monstruo con la curiosidad y la certeza de que la maldad que se le atribuye no es verdadera. Éste se va a materializar en un huido con quien establece una relación sin palabras. La inocencia de la niña es el reflejo parabólico de la nueva generación que asiente con devoción e ingenuidad a las divisiones del pasado y que aún sufre la brutalidad de unas muertes incomprensibles.

La idea de incluir en El espiritu de la colmena la figura de un guerrillero fue de Ángel Fernández Santos, co-guionista de la película. En su infancia, Fernández Santos había convivido con un maquis; su padre, maestro republicano represaliado, lo había escondido en el pajar ${ }^{63}$. Presentada a concurso en el Festival de San Sebastián de 1973, obtuvo la Concha de Oro ${ }^{64}$.

Mucho más dramático será el caso de Paca (Conchita Velasco), la protagonista de Pim, pam, pum iFuego!, una cupletista sin trabajo, quien se enamora de Luis (José María Flotats), un maquis que ha conocido en el tren y que esconde en la habitación realquilada donde vive con su padre, un viejo republicano paralítico y desencantado. A Paca le pretende Julio (Fernando Fernán Gómez), un estraperlista sin escrúpulos que, corroído por los celos, persigue a la pareja hasta acabar con la vida de ambos.

Luis encarna el amor puro, la belleza, unos ideales que Paca admira. Ella no quiere mancillar el amor que siente por Luis entregándose a Julio. Gracias a su posición, el

63 FERNÁNDEZ SANTOS, Ángel: "Las paradojas de El espiritu de la colmena", El País, 21-8-83.

64 AGA, SC, 36/4237. De todo el conjunto de películas sobre el maquis, ésta es la única que eleva el espíritu de la Junta de Clasificación; cuanto menos la catalogan de "bello poema cinematográfico", "un film hecho con amor", "el film te recrea dentro sin efectismos", "si algo es este cine es eso, CINE"... sin apenas poner objeciones a su proyección. También hay quien lo califica de "tenebrista" (Sáenz de Heredia) y "hecho para un público minoritario" (Juan Wesoloski). 
estraperlista consigue que la despidan para que, acuciada por la pobreza, dependa sólo de él. Cuando finalmente la "compra", Julio la viola, le dispara y arroja su cuerpo a un descampado. Estrenada el 5 de septiembre de 1975, Pim, pam, pum ;Fuego!, fue un film rodado cuando aún no se podían expresar los temas abiertamente aunque a estas alturas la Junta admitió sin recelos este "tema de época bien ambientado e interpretado"65. De forma oblicua, Pedro Olea (1938) y Rafael Azcona (1926-2008) se sirvieron de un triángulo amoroso para representar las dos Españas que aún pervivían. Pero ahora esta metáfora invierte sus valores, la bondad y la belleza están encarnadas por un maquis y una cupletista mucho más dignos que los afectos al Régimen.

Aún se filmarán dos películas más alusivas a la guerrilla en los postreros años de la dictadura, Metralleta Stein (1975) y Casa Manchada (1980). La primera, dirigida por José Antonio de la Loma (1924-2004), en principio se basaba en la vida de Quico Sabaté pero, como en casos anteriores, por las exigencias de la censura y de la Guardia Civil fue imposible darle un toque político al guión ${ }^{66}$. Estrenada el 27 de enero de 1975, la película, cuyo primer título era Duelo a muerte y hubo de cambiarse por imposición de la Guardia Civil ${ }^{67}$, resultó ser otro thriller policiaco donde, a la postre, un delincuente, Mariano Beltrán (John Saxon), es perseguido obsesivamente durante 12 años por un policía (Francisco Rabal) hasta morir ambos a la par.

Casa Manchada fue la última película del franquismo que se acerca a la figura de los maquis: su expediente se inicia en diciembre de $1974^{68}$. El productor y guionista, Andrés Velasco, había comprado los derechos de la novela de Emilio Romero Todos murieron en Casa Manchada, publicada en 1959, y se la había entregado a José Antonio Nieves Conde (1911-2006), el viejo director de la arriesgada y polémica Surcos. Según Nieves Conde "Lo más sensato hubiera sido tirar la historia a la papelera" ${ }^{69}$. El guión era deslavazado, demasiado explicativo y "atiborrado de párrafos" ${ }^{70}$. Por mucho que intentó arreglarlo agilizando los diálogos, reforzando la línea argumental y añadiendo un toque social a la actitud de los maquis, el film resultaba bastante mediocre y anacrónico; el tema, acartonado e improcedente. De hecho, la película no se estrenó en España hasta el 9 de junio de 1980, cinco años después de rodada ${ }^{71}$.

El argumento principal discurre durante una avanzada posguerra cuando una partida de maquis asalta la finca de Álvaro (Stephen Boyd). El jefe guerrillero, tras acusar a Álvaro de cacique "Eres un explotador que vives a costa del sudor del obrero" y anunciar al personal que volverán "para dar la tierra a quien la trabaja", lo secuestra. Le exige un "tributo de un millón de pesetas" para su causa política: "Somos

65 Ídem, SC, 36/5166. La Junta estimó que el tema político estaba bien tratado, "sin que resulte tendenciosa". Sólo exigían suprimir las palabras malsonantes y aligerar el coito entre Julio y Paca.

66 AGA, SC, 36/5151. José Antonio de la Loma se comprometió a no hacer ninguna referencia a Quico Sabaté. La Junta consideraba inoportuna su proyección: el ambiente político estaba muy crispado tras la ejecución de Salvador Puig Antich (2-3-74) y los consejos de guerra y condenas a muerte pendientes, que se ejecutarían en septiembre de 1975. Por otra parte, en 1974 ETA había cometido 18 asesinatos.

67 Ibídem. Informe de José Antonio de la Loma, 9-9-74.

68 AGA, SC, 36/5163.

69 LLINÁS, Francisco: José Antonio Nieves Conde. El oficio del cineasta, Valladolid, Semana Internacional de Cine de Valladolid/SGAE, 1995, p. 136.

70 Ibídem.

71 En abril de 1977 se estrenaba en Estados Unidos. 
un ejército y necesitamos provisiones", le explica. Los distintos parlamentos entre Álvaro y el guerrillero, quien pretende exponer sus razones para la acción revolucionaria, no resultan convincentes. Entretanto, la esposa de Álvaro intenta pagar el rescate, pero la intervención del gobernador civil, amigo de la familia, provoca el fatal desenlace, muriendo la partida y el protagonista. La propia Junta lo calificó de "flojo en el desarrollo y en la interpretación. Francamente flojo"72. La crítica, más condescendiente, lo consideró "simplemente mediocre" 73 .

\section{De la delincuencia al mito}

A pesar de las miradas favorables del cine, al iniciarse la Transición, el discurso oficial conservaba su inercia. Para abundar sobre él, en 1975 y 1976 el entonces teniente coronel de la Guardia Civil, Francisco Aguado publicó dos extensos libros, El maquis en España y El maquis en sus documentos que, a lo largo de casi 800 y 500 páginas respectivamente, de manera minuciosa y sesgada explicaba quiénes eran y qué habían hecho entre 1943 y 1955 los guerrilleros: 953 asesinatos, 5.963 atracos y 8.267 actos delictivos, además de matar a 257 guardia civiles y herir a 370. En estos textos se resalta la importancia de su extinción y la encomiable labor de Benemérita ${ }^{74}$.

La primera película de la Transición, El ladrido de Pedro Lazaga, posiblemente inspirada en las vidas de los guerrilleros cántabros Juanín y Bedoya ${ }^{75}$, y estrenada el 30 de octubre de 1977, reflejaba una vez más todos los tópicos que definían al maquis, eso sí, aderezados con el erotismo propio del destape tardofranquista ${ }^{76}$. No obstante, el director traspasa los estereotipos y brinda una lección moral que rompe con el maniqueísmo tradicional: si los maquis son malvados, el resto de los protagonistas son corruptos y depravados. Avaricia, lujuria, ira... los siete pecados capitales definen a los habitantes del caserío donde se han refugiado unos guerrilleros tras un atraco. Y por ello, todos van a recibir como castigo moral la muerte. Sólo la más joven de la familia, la única compasiva, logrará sobrevivir al drama, además de quedarse con el botín engañando a la Guardia Civil, lo que también encierra otra parábola sobre este período. Los guerrilleros ya no son individuos extraños, ajenos; como un miembro más de la sociedad española, presentan los vicios y las virtudes nacionales. Así, al ser integrados y reconocidos, a partir de este momento la imagen de los maquis va a ser diferente. El estereotipo nuevo va a estar teñido de humanidad, uniéndose a su destino el de aquellos que integran su microcosmos y que aceptan las consecuencias de la derrota y del sinsentido.

\footnotetext{
72 AGA, SC, 36/5163. Además de diferentes críticas negativas, sólo se insiste en la supresión de las palabras soeces.

$73 A B C, 12-6-80$.

74 Para contrarrestar, durante 1975 también publicó Carlos J. KAISER: La guerrilla antifranquista, la historia del maquis, Barcelona, Ediciones 99, una obrita de poco más de 100 páginas donde se pretendía dignificar la lucha guerrillera.

75 MAROTO CAMINO, Mercedes: Film, Memory and the Legacy of the Spanish Civil War. Resistente and Guerrilla, Hampshire, Palgrave Macmillan, 2011, p. 78.

76 AGA, SC, 36/5251. Se mandó cortar el plano en que se veía el sexo de la protagonista.
} 
El público, la sociedad española, también estaba cambiando. Ya no resultaba válido el maniqueísmo a ultranza de la etapa anterior. Una corriente revisionista buceaba e investigaba sobre el pasado inmediato ${ }^{77}$. Se añoraba el tiempo perdido y se pretendía recuperar el pasado. Y entre lo recuperable estaban los perdedores de la guerra. Pero, en muchos casos, ese rescate sólo conducía a la desolación, pues se trataba de evitar que el fracaso alcanzase su propia victoria, porque no había redención posible.

Y si durante el franquismo la lucha de los maquis había sido velada, durante la Transición, el gobierno dio carpetazo ${ }^{78}$. La política gubernamental se encaminó hacia un pacto de silencio y olvido. La Ley de Amnistía exculpó "todos los actos de intencionalidad política, cualquiera que fuese su resultado, tipificados como delitos y faltas realizados con anterioridad al día 15 de diciembre de 1976." (Ley 46/1977 de 15 de octubre). Este punto final negaba el reconocimiento a quienes durante treinta años persistieron en combatir un régimen que consideraban ilegítimo. El pasado quedaba enterrado. Incluso el PCE trató de minimizar y de excluir de su historia oficial a los guerrilleros. Al reescribir su pasado para integrarse en la legalidad parlamentaria, el maquis devino en un acontecimiento marginal, casi anecdótico que incluso quedó borrado de la memoria personal de sus impulsores ${ }^{79}$. Como si las viejas heridas retrasaran la reconciliación y fuera un sinsentido abrir las ya cicatrizadas: entre 1975 y 1996, el maquis apenas ocupó espacio ni en la literatura ni en el cine, poco más de una novela al año ${ }^{80}$ y cuatro películas: dos durante los catorce años del gobierno de Felipe González.

En estos filmes, con gran contención y sobriedad, el maquis no sólo adquiere unas características diferentes, sino que ocupa un lugar hegemónico, hasta trasladar la visión del mundo a través de sus ojos. Algunos aspectos como la persecución y el abandono o la traición de las cúpulas políticas -que han puesto fin a la lucha- se mantienen. Por lo tanto, el resistente va a adoptar una actitud de retirada, pero sin los tintes de arrepentimiento anteriores. Respecto a los vencedores, se invierten los papeles, éstos y sus fuerzas represivas se revisten de crueldad mientras que el maquis únicamente está a la defensiva. Otro rasgo sobresaliente será su humanidad, son personajes con dudas, temores y contradicciones. Por último, ahora no están solos; una continua relación con los del llano que les aman, apoyan y sufren con ellos, será otra constante. A pesar de su derrota, hay una extrema dignidad en ella. Unos directores, comprometidos en rehabilitar su memoria, invitan a los espectadores a derribar los tópicos. Desde las instancias gubernamentales ya no hay

77 Sobre las publicaciones de estos primeros momentos de la Transición, véase Santos JULIÁ: Memoria de la guerra y del franquismo, Madrid, Taurus, 2006.

$78 \mathrm{Si}$ bien se dictaron una serie de leyes que trataban de compensar a quienes habían sufrido penalidades durante la guerra en el bando republicano o prisión durante el franquismo, como el Decreto 670/1976 por el que se regulaban las pensiones a los mutilados republicanos, la Ley 5/1979 sobre el reconocimiento de pensiones a hijos y viudas republicanos o la Ley 37/1984 de reconocimiento de derechos y servicios prestados durante la guerra civil, entre otras.

79 SERRANO, Secundino: Maquis: historia de la guerrilla antifranquista, Madrid, Temas de hoy, 2001, pp.15-16.

80 Durante la Transición y el periodo socialista sólo se escribieron 36 obras de ficción referidas al maquis de las 201 publicadas entre 1938 y 2012. En cuanto a los ensayos, se le dedicaron 64 de los 335 redactados hasta 2012. www.lagavillaverde.org 
indicación alguna sobre la postura que productoras, guionistas y directores han de tomar acerca de su tratamiento ${ }^{81}$.

El primero que así lo hizo fue Mario Camus (1935) en $1976^{82}$. Con una sensibilidad exquisita, sin sensiblería ni condescendencia, presenta en Los días del pasado a Juana (Marisol), una maestra malagueña enamorada de un huido, Antonio (Antonio Gades), que se traslada a un pueblo perdido del norte, por si existiera alguna posibilidad de reencuentro. El frío, el hambre, la tristeza de la dura posguerra acompañan a todos los personajes en un paisaje húmedo, brumoso y hosco; la geografía adquiere un protagonismo inusitado, acentuando la melancolía de los personajes ${ }^{83}$. La partida ya no la integran una banda de ladrones egoístas, la decencia les acompaña cuando entregan un recibo a cambio de comida y la nobleza impera si hay que arriesgar la vida para recoger a un compañero herido. Es patente también la fidelidad de los que comparten su causa: "Me acordé de ti todo el tiempo", susurra Juana en su primer encuentro. "Tiempo perdido", contesta él. Lealtad y respeto que vuelve a manifestarle en su segundo encuentro, al animarle Juana a proseguir la lucha: "Haz lo que tengas que hacer", a lo que él responde: "Y tú también". No se volverán a ver: mientras los niños recitan en su nueva clase, otra vez en el sur, la mirada perdida de Juana le acerca a los gemidos agónicos de quienes siguen luchando en el monte.

Silencio, horas de espera, de incertidumbre, de soledad sin llanto. Un amor romántico donde no hay ni un beso ni un abrazo en el primer encuentro, simplemente él la acaricia y ella aprieta su mano. En la segunda cita, Antonio rendido duerme sobre la mesa de la taberna; Juana, vela su sueño; la única escena de amor sólo destila una apasionada suavidad. "El destino, la fatalidad se ocuparán de hacer imposible, de destruir ese amor dislocado." 84

La desolación también embarga a los guerrilleros. Al contrario que en la época anterior, el jefe establece una relación paternal con sus hombres. Ante sus dudas y miedos, refuerza sus convicciones: “¡Juaneloo! -grita a uno que está de guardia- ¡Qué hacemos aquí!" "Estamos, ¿no?" -responde el interpelado-. "Estamos, eso es, algún día haremos algo más. Vendrán los que están fuera y daremos la cara, pero ahora somos muy pocos. Y cada vez que me muevo pienso en la vida de cada uno, en no desperdiciarla. Me conformo con que los de abajo sepan que estamos aquí, que no nos hemos rendido, que la guerra va a durar mucho más tiempo del que nosotros duremos (...) ¡Estamos!" En Los días del pasado los guerrilleros no muestran una ideología concreta, sólo resisten, sólo están en contra de Franco y así Camus los retrata en sus momentos postreros. Este final inexorable se acerca perfilado por los matices individuales que confieren dignidad y grandeza a una lucha colectiva ${ }^{85}$.

81 Declaraciones de Mario Camus a la autora, 12-5-10.

82 AGA, SC, 36/5239. El 28 de septiembre de 1976 se presentó el proyecto al Sindicato Nacional del Espectáculo y el 18 de octubre se iniciaba el rodaje.

83 FURGONE, Juan Carlos: Oficio de gente humilde...Mario Camus, Valladolid, Semana de Cine de Valladolid, 1984, p. 123

84 Declaraciones de Mario Camus a la autora, 12-5-10.

85 AGA, SC, 36/5239. La productora no solicitó la categoría de Interés Especial en su momento pues se le "insinuó" que le derogarían el permiso de rodaje al tratarse de un tema que hacía "apología del maquis español". 
Frente a la memoria realista y fatal de Los días del pasado, Manuel Gutiérrez Aragón muestra en El corazón del bosque la memoria mítica. En los momentos en que se rueda la película, 1978, el grupo dirigente del PCE instalado en Francia regresa a España y se enfrenta, no sin tensiones y desajustes, a las organizaciones sectoriales del interior, de las que Gutiérrez Aragón formaba parte. Pero no será sólo esta clave interna la que apunte el director en El corazón del bosque, sino la remembranza de un hecho ocurrido cuando aún estudiaba en el instituto de Torrelavega (Santander), la muerte de uno de los últimos maquis cántabros, Juanín (Juan Fernández Ayala), en 1957, bajo los disparos de la Guardia Civil ${ }^{86}$. La imagen popular había hecho de Juanín un mito local y éste será el referente principal que se utilice para revestir a $E l$ Andarín (Luis Politti) con un halo elegiaco y lírico ${ }^{87}$. El Andarín representa un mito legendario, un innombrable, el último combatiente de una batalla que ya no se libra.

El protagonista de la trama es Juan (Norman Briski), un comisario político hermano de Amparo (Ángela Molina), la niña que amó a El Andarín y que durante años le ha ayudado, que regresa para liquidar al último resistente y así también liberar del mito a los que tiene atrapados. Se trata, pues, de un enfrentamiento cara a cara entre el guerrillero y el joven militante: "Tienes que dejarlo, jobedece, es irremediable! Estás enfermo, somos tus camaradas, somos tus amigos, he venido a ayudarte", mientras ambos son acorralados por la Guardia Civil. El corazón del bosque es sobre todo una especie de "ajuste de cuentas poético con la Historia" 88.

La lealtad de El Andarín estará por encima de la propia supervivencia cuando ayude a un Juan herido, a pesar de perseguirle, a pesar de saberse acorralado. El antihéroe tomará conciencia de su propia condición frente a la dignidad del acabado guerrillero y en un juego de sombras sobre un risco -como hacía El Andarín en el pasado antes de bajar a bailar a la romería burlando a la Guardia Civil-, Juan se trasmuta en su perseguido una vez que aquél se ha perdido en la niebla. Pero la realidad es inexorable y Juan ha de tornarse en el verdugo de esa derrota histórica acabando con la leyenda para, a su vez, ser denunciado por los suyos. Al otorgar a los maquis un lugar mítico, al reconocer el valor de su lucha, Gutiérrez Aragón, en cierta medida, resarce la deuda histórica contraída por la sociedad española con aquellos que habían entregado su vida en aras de un ideal, a la vez que denunciaba su sacrificio.

Hasta nueve años después, iniciado ya el segundo mandato de Felipe González, los maquis no volverán a la pantalla. Pareciera como si los dos filmes anteriores, al haber reflejado con nostalgia y dignidad aquel combate perdido utilizando dos registros complementarios, la realidad y el mito, lo hubieran situado ya en el mundo de las ensoñaciones casi imaginarias.

\footnotetext{
86 Declaraciones de Manuel Gutiérrez Aragón en el capítulo "Los del monte" de la serie La memoria recobrada (Alfonso Domingo, 2006) producida por TVE. A la vivencia personal de Gutiérrez Aragón, se unió la del productor de la película Luis Megino quien aportó sus recuerdos sobre los maquis asturianos, completando la investigación con entrevistas hechas a vecinos de ambas provincias. Rodaron la película en los escenarios reales donde los maquis habían vivido. Declaraciones de Luis Megino a la autora, 14-5-10.

87 TORRES, Augusto M.: Conversaciones con Manuel Gutiérrez Aragón, Madrid, Fundamentos, 1985, pp. 99-101.

88 HEREDERO, Carlos F.: Manuel Gutiérrez Aragón: las fábulas del cronista, Madrid, Iberautor/Ocho y Medio, 2004, p. 129.
} 


\section{Utopía y ucronía durante el primer socialismo}

Un brusco despertar de las conciencias fue Luna de lobos (1987), basada en la novela de Julio Llamazares y publicada en 1985. Llevada al cine dos años después por Julio Sánchez Valdés, ofrecía a la sociedad española una visión desgarradora del género humano: la persecución implacable del hombre por el hombre hasta su transformación en alimaña.

Según el argumento, en noviembre de 1937 cuatro combatientes republicanos huyen del avance nacionalista por los montes de León. Allí, aislados, luchando contra el clima y una naturaleza hostil, verán transcurrir los años de la guerra y la posguerra, hasta asumir que ya no hay sitio para ellos. Fuera de su microcosmos, las coordenadas histórico-temporales que transcurren desde la caída del frente de Asturias hasta el abandono de los guerrilleros a su suerte en 1946, son meras pinceladas de una trama enfocada en la degradación de los huidos: "Hueles a monte Ramiro, como los lobos... peor, a los animales no los tratan como a vosotros", constata María (Kiti Manver), al encontrarse con Ramiro (Santiago Ramos), su antiguo novio, después de una larga separación. "¿Y que hacemos, nos entregamos?” No hay alternativas. El acoso los convierte en homicidas desesperados al disparar contra un paisano en un asalto a una taberna. La acción sólo conduce a una dramática conclusión: "Ya no tenemos vuelta atrás", que constata una cruel realidad: “¿Y cuándo la hemos tenido?"

Los del monte, incluso, se convierten en una rémora para los suyos: "Yo también he sabido lo que es el miedo o la soledad. No ha sido más fácil para los que estábamos aquí" -alega María cuando Ramiro la descubre en la cama con el cabo de la Guardia Civil-. Incluso se vuelven incómodos para sus perseguidores, acuciados por los mandos: "Tiene una semana para cogerlos, vivos o muertos". En definitiva, no hay escapatoria, se trata de un suicido colectivo. Tras regresar y ser escondido en un zulo del tamaño de un ataúd, Ramiro llega a la única conclusión posible: "Esta tierra no tiene perdón, está maldita para mí". Por otra parte, el sufrimiento de quienes comparten y han compartido su trayectoria adquiere aún mayor relevancia, no se trata sólo de una tragedia personal, sino que afecta a una parte desengañada y desolada de la sociedad española. Pero, en contraposición al estereotipo del periodo franquista y en clave actual, en Luna de lobos los maquis incluso perdonan a quienes se arrogan el derecho del máximo perdón: otro de los protagonistas, Ángel (Antonio Resines), desiste de disparar al cura que denunció a su hermano.

La segunda película que se rueda durante el periodo socialista, a pesar de estar llena de lugares comunes, ofrece un aspecto curioso: las diferencias ideológicas y operativas de distintas partidas. Pero lo más relevante es que por primera vez se eleva a un guerrillero a la condición de héroe. En Huidos (1993), Sancho Gracia (1936$2012)^{89}$-director y productor del filme- encarna a Juan Márquez, un anarcosindicalista gallego que, junto a otros vecinos, huye al monte durante la guerra y permanece escondido ocho largos años. Juan es un cuerdo pacifista: "[La democracia] se consigue día a día ganando las conciencias." No quiere convertirse en un amargado y violento superviviente como su amigo Marcial (Fernando Valverde), que sólo piensa

89 Aunque nació en Madrid, al exiliarse sus padres, pasó su infancia en Uruguay. 
en la venganza tras el asesinato de su mujer y su hija. Éste se verá envuelto en una espiral de violencia a la que arrastra a su grupo, una partida comunista militarizada que sigue las consignas del Partido: "Nuestra filosofía es la de la Unión Nacional, todos contra el nacifascismo", tal y como les adoctrina un intelectual llegado hasta ellos. Marcial representa los clichés ya manidos durante el franquismo; es brutal al asesinar al señorito y no admite la deserción: dispara a quien desee entregarse. Perpetra atracos, lanza panfletos, roba, asesina... actividades de las que Juan no es partidario. El director presenta aquí cierto devaneo con la imagen tradicional del maquis aunque, finalmente, Marcial se hace matar por la Guardia Civil cuando Juan es capturado, en un acto de solidaridad masculina cuasi decimonónica. Juan, por su parte, es juzgado y encarcelado. En su alegato argumenta: "No soy un bandido como se dijo en esta sala, tampoco un pobre ni un incauto, como dijo mi abogado. He estado huido y perseguido en el monte durante más de ocho años y he llegado hasta aquí sin sangre en las manos. Siempre he respetado la libertad de los demás, creo que soy inocente de las acusaciones que se me hacen. No he hecho más que intentar sobrevivir, a nadie puede negársele este derecho." En el epílogo, una voz en off nos informa de que Juan Márquez cumplió cinco de los diez años de su condena en la isla de San Simón (Pontevedra) y acogido a indultos, por su buen comportamiento, fue excarcelado, rehaciendo su vida al lado de la mujer amada.

Huidos se hace eco del discurso dominante sobre la guerra civil que se elabora durante los años ochenta; un discurso que pretende primar la representación de "la naturaleza humana universal sobre la particularidad de una guerra que nos alejaba de una modernidad mal entendida." ${ }^{90}$ Asimismo queda patente en el filme la inocencia de los guerrilleros, todos presos de un fatum que les convierte en víctimas de la omnipotencia del Mal. Eso sí, cada uno va a utilizar su libre albedrío para actuar en consecuencia, tomando diferentes caminos, la paz o la violencia. Juan, que utiliza mejor sus recursos frente a la adversidad, puede muy bien constituir el estereotipo de "hombre bueno" tradicional, cuya virtud es premiada defendiendo, además, sus derechos.

También en Huidos, por primera vez se refleja la acción política del Partido Comunista, la organización que se pretende implantar desde Francia en las partidas, así como su discurso ideológico. La lucha política es descrita a través de una serie de ágiles secuencias que muestran acciones de concienciación a la sociedad y el adiestramiento de los jóvenes guerrilleros.

Un paso más a la hora de eliminar el extrañamiento del maquis en la sociedad española vino de la mano de Antoni Ribas (1935-2007) y su Terra de canons (1999). Iniciada la producción en 1993 no pudo concluirla hasta $1999^{91}$. En su línea personal de reivindicar a los perdedores de la guerra civil, Terra de canons relata el devenir de varias familias catalanas entre 1938 y 1952. Y la mayor aportación de Ribas a esa aceptación del maquis como parte de nosotros será la de convertir al hereu de los aristócratas Siscart (Lorenzo Quinn) en jefe de una partida que, entre otras accio-

\footnotetext{
90 MORENO NUÑO, Carmen: "La representación del maquis en la historia del cine español: de bandoleros a guerrilla antifranquista”, Letras peninsulares, 16 (2003), p. 362.

91 Durante diez meses Ribas protagonizó una sentada frente a la Generalitat tras denegarle la subvención. Cinco años después, con la ayuda de 300 productores y 350.000 firmas obtuvo la financiación necesaria para su película. El mundo, 4-10-2007.
} 
nes, pretende atentar contra Franco durante el Congreso Eucarístico de Barcelona. El compromiso de los protagonistas con la lucha clandestina, representantes de la elite tradicional de la sociedad española, exonera, en parte, a los guerrilleros de su estigma social y moral.

\section{La desmitificación del mito}

Rayano el siglo XXI, sesenta años después de la guerra, la guerrilla, como lucha política, al menos para el cine, resulta ya un asunto del pasado. No así para la novela o los estudios históricos, que van a dar sus mejores resultados en estos años. La trilogía de Alfons Cervera -El color del crepúsculo (1995), Maquis (1997) y La noche inmóvil (1999)-, El puente de hierro de César Gavela (1998) y La noche de los cuatro caminos de Andrés Trapiello (2001) reivindican una época olvidada durante la Transición, a través de la memoria personal y generacional. En ellas desaparece el discurso ideológico excesivamente politizado, en cierto modo, gracias a la caída del Muro de Berlín y a la desintegración del bloque comunista. Por otro lado, las investigaciones de Secundino Serrano y de Francisco Moreno, publicadas en 2001, así como los diferentes trabajos que analizan la lucha guerrillera en gran parte de España, sitúan a los guerrilleros antifranquistas en un primer plano del debate histórico sobre su memoria. A partir de estos años, se han publicado un elevado número de estudios que han analizado en profundidad las agrupaciones guerrilleras en gran parte del territorio nacional ${ }^{92}$.

Con independencia de este debate, el cine va a considerar ya integrada la figura del maquis como un elemento más de la intrahistoria nacional. Incluso Gonzalo Suárez (1934), nada más comenzar el milenio, adopta un registro jocoso para su presentación en El portero (2000), donde el discurso pacifista prima frente al maniqueísmo simplista que intenta explicar la compleja realidad humana. Se trata de una comedia coral, amable, basada en un relato del crítico Manuel Hidalgo, donde en una playa y a golpe de balón, se dirimen las diferencias entre izquierdas y derechas, entre el maquis y la Guardia Civil... con la Iglesia como árbitro.

La acción transcurre durante 1948, Forteza (Carmelo Gómez), una vieja gloria del balompié, se gana la vida parando penaltis por los pueblos. De camino a su próxima actuación es detenido por Nando (Eduard Fernández), el jefe de unos maquis locales, que le obliga a transportarle a su aldea escondido en la trasera del camión. En el recorrido, también le da el alto el sargento Andrade (Antonio Resines) quien, al reconocerle, con gran júbilo, le recita entera su alineación, mientras su compañero revisa la furgoneta. "Dame un cigarro, Rafa" susurra Nando al joven guardia que lo descubre y que, con mirada cansina, se lo enciende. Al llegar al pueblo, Nando le da una manzana mordida a Forteza como contraseña para entregársela al tabernero, manzana que éste recoge con cara de aburrimiento.

A estos maquis también les llegarán las órdenes de Toulouse de abandonar la lucha armada: "¿Y qué haremos?" -pregunta uno- "No daremos ni un paso atrás”-responde

92 Además de los ya citados en este trabajo, existe una relación completa en www.lagavillaverde.org 
Nando zanjando la cuestión-. De ellos no sabremos más hasta el final de la cinta, cuando bajan del monte para representar a los maltrechos paisanos, a la hora de dirimir quiénes son los mejores jugando al fútbol, si la Guardia Civil o los maquis, únicos en condiciones para representar al pueblo. La pugna acaba en empate; los maquis junto con los lugareños protegen a un Forteza lesionado, incapaz de continuar la competición. En el último plano, el agua de la orilla deslíe los colores de la bandera española pintada sobre el balón...

En You're the one (Una historia de entonces) (2000), de José Luis Garci (1944), mucho menor será la presencia, o ausencia, del marido de Pilara (Ana Fernández) quien, al poco de comenzar la guerra se echó al monte, y se desconoce su paradero tres años después. Apenas tres secuencias merece el drama de la criada, comparado con el de la señorita Julia (Lydia Bosh), que pena la muerte de su marido, un famoso pintor, preso en Alcalá de Henares. Una mirada a una foto al escucharse unas ráfagas, un diálogo intimista y femenino: "Estaba pensando en qué diría si me viera así -comenta Pilara mientras se prueba un traje de Julia- y una referencia a los disparos de la noche anterior: "Yo no creo que siga arriba, según los rumores, se pasó a Francia. Lo que sí sé es que está vivo", es todo lo que queda de una figura fantasmal integrada en el transcurso de la vida.

Los maquis también formarán parte de esa cotidianeidad de las mujeres en Silencio roto (2001). Montxo Armendáriz (1949) plantea, además de una seria reflexión sobre el sentido de la resistencia ética, un nuevo paradigma: la perspectiva de quienes realmente sufren los enfrentamientos entre los maquis y las fuerzas del orden, la visión de sus seres queridos, y sobre todo, de sus mujeres. Aunque otros filmes se hayan acercado a este tema, tanto de uno como de otro bando, será aquí donde se analicen las consecuencias con dramática crudeza: las mujeres no sólo pagaron por sus ideas sino también por las de los hombres de su familia ${ }^{93}$.

Así lo expresa Teresa (Mercedes Sampietro) "Por qué siempre nos tocará sufrir a nosotras", la tía de Lucía (Lucía Jiménez) una joven que regresa a un pueblo del Pirineo navarro en 1944 para trabajar en la taberna familiar. También lo enuncia Rosario (Alicia Sánchez) esposa de un maquis que lleva varios años en el monte y que bajará para tomar el pueblo, con la intención de hacer una criba entre los fascistas: "Para vosotros es fácil dar escarmientos, los dais y desaparecéis, y nosotras qué, ¿qué va a ser de nosotras cuando vosotros os vayáis?” De hecho, Rosario, tras arrestos y palizas, optará por ahorcarse. La propia Lucía, que apoya la lucha y actúa de enlace, tiene sus dudas: “¿Crees que servirán de algo estas muertes?... Ahora otra vez la guerra...", le pregunta a Manuel (Juan Diego Botto), el joven de quien se enamora. Lucía se marcha al quedarse embarazada y regresa un año después para saber de Manuel. Entre tanto, los enfrentamientos entre los propios maquis y con la Guardia Civil han diezmado la partida. Manuel caerá, pero no será el último. Entre otros morirá el cabo de la Guardia Civil, su joven esposa, que en ocasiones ha pasado información, sufre como el resto de las mujeres. Ella también acompañará en silencio el cadáver de su marido. La otrora resistencia ética ha devenido en épica, pero ha

93 Véanse testimonios en GARCÍA, Consuelo: Las cárceles de Soledad Real, Barcelona, Alfaguara, 1983, p. 34 . 
minado de tal modo la vida del pueblo que finalmente se tornará en un cementerio sembrado de traiciones, delaciones y muerte.

Esta situación aún va a crear otras víctimas que también sufren en su propia carne las consecuencias, los niños. Desde su perspectiva se tratará el tema de los maquis en dos de las últimas películas que lo abordan: El embrujo de Shangai (Fernando Trueba, 2002) y El laberinto del fauno (Guillermo del Toro, 2006). Entre ambas, Jaime Chavarri filma en 2004 El año del diluvio donde reviste a los guerrilleros con los atributos de "bandidos justicieros" pues, tras un robo al cacique local, donan el botín para la construcción de un asilo de ancianos.

Las propuestas de Trueba (1955) y Del Toro (1964) bien pudieran ser el epílogo de este estudio, la muerte de la inocencia, su utilización por unos y otros para obtener argumentos que afirmen sus ansias de dominio y poder.

El embrujo de Shangai gira entorno a la relación entre dos adolescentes en la Barcelona gris de la posguerra: Susana (Aida Folch) -una jovencita tísica y consentida por una madre alcohólica y drogadicta (Ariadna Gil) cuyo padre ausente, el Kim (Antonio Resines) encarna a un maquis aventurero afincado en Francia-, y Dani (Fernado Tielve), enamorado de la déspota Susana, tímido y soñador, a través de cuyos ojos el espectador irá perdiendo la inocencia. Para ambos el Kim es el héroe mítico que emprende arriesgadas misiones. Dos personajes más constituyen la trama: el misterioso Forcat (Eduard Fernández), amante de la madre, amigo del Kim y forjador de las fantasías de los adolescentes y Denis (Jorge Sanz) -la encarnación del mal-, antiguo camarada del Kim y de Forcat, quien les destruirá y prostituirá a Susana. Nada se va a salvar de la maldad, la envidia, los celos y la degradación del quinteto, cada uno perverso a su manera, dejando una estela de dolor y desencanto como herencia a Dani, el espectador ingenuo: para él ni siquiera habrá una mirada de reconocimiento cuando, años después, vaya al encuentro de Susana, del pasado.

Más dramática aún resulta la fábula de Guillermo del Toro. Aquí, a quien se demoniza es al capitán Vidal (Sergi López) de la Guardia Civil, psicópata, cruel y ególatra que persigue y tortura con saña a los maquis en el Pirineo navarro durante 1940. Casado en segundas nupcias con Carmen (Ariadna Gil) quien, muy enferma y en avanzado estado de gestación, se traslada junto a su hijita Ofelia (Ivana Baquero), despreciada por Vidal, al molino donde éste tiene su centro de operaciones. Ofelia, para huir de la crueldad y la desolación, inventa un mundo fantástico que se entrelaza con la realidad. Pero ambos planos resultarán igual de implacables, en ninguno hay redención: alcanzar la felicidad exige la expiación de los inocentes. $\mathrm{Y}$ en ambos mundos encontrará Ofelia la muerte al dar su vida a cambio de la de su hermano recién nacido hijo de Vidal. Esta elección, muestra de su entrega generosa, le permitirá alcanzar la recompensa: resucitar en un universo diferente. Una voz en off revela la moraleja final destinada a los iniciados: "Se dice que la princesa (...) dejó tras de sí aquellas huellas de su paso por el mundo sólo visibles para aquel que sepa dónde mirar." 


\section{Conclusiones}

A lo largo de sesenta años, el cine ha presentado a la sociedad española una imagen de los maquis acorde con la ideología política de cada momento. Su tratamiento no ha sido sencillo, su percepción dual, héroes para unos, asesinos para otros, les ha conferido un carácter complejo que no ha resultado ajeno a la pantalla.

Respecto al periodo franquista, la forma de abordar el fenómeno del maquis, no puede considerarse como un documento fidedigno del proceso histórico, sino más bien un testigo de la manipulación a la que fueron sometidos directores y guionistas. Un cine sesgado que trasluce esa exigua parte del mensaje lanzado por habilidosos cineastas diestros en burlar la férrea censura. Por otra parte, los directores afectos al Régimen ofrecían un testimonio más acorde con el ideario franquista, apoyando el discurso más conveniente en cada momento de cara al exterior.

Así, la construcción de la imagen del maquis en este periodo estuvo definida por estas dos tendencias. Por un lado, la de los directores que querían infundirles una cierta dignidad al representarlos como individuos equivocados que reconocían su error y demostraban su arrepentimiento. Y por otro, la de los que hicieron de ellos personajes crueles, egoístas y delincuentes, pero siempre perdedores, condenados de manera inexorable a la muerte. En ambos casos las directrices de la Junta de Censura prevalecieron sobre las ideas que realizadores y guionistas pretendían mostrar. $\mathrm{Su}$ gran preocupación fue evitar que despertara en el público un sentimiento de compasión o comprensión que avivara cualquier duda sobre la legalidad del Régimen. En la mayor parte de los casos, productoras y directores conscientes de que cualquier matiz político podía frustrar la realización de un film, se cuidaron mucho al definir a los guerrilleros hasta imposibilitar su identificación, por lo que la censura solamente incidía en la moralidad de las imágenes.

También la situación política nacional e internacional y las propias corrientes cinematográficas van a influir en la representación del maquis en la pantalla: del reconocimiento oblicuo que se efectúa durante los cincuenta se pasa a un alejamiento casi cruel en los 60; su exterminación era, para el Régimen, la expresión legítima de la soberanía histórica de España.

En los últimos años de la dictadura se añaden nuevos elementos a la elaboración de los personajes, abandonándose el maniqueísmo anterior: la equiparación de vencedores y vencidos en los peores y mejores rasgos de la humanidad. Aparecen igual de perversos unos que otros y los maquis serán ahora merecedores del amor y la entrega de quienes se acercan a ellos.

A partir de la muerte de Franco, una serie de directores pretendieron mutar su imagen negativa por un reconocimiento a su resistencia ante el fascismo y conferir una dimensión heroica a su lucha. Pero el miedo arrastrado desde el pasado durante la Transición impidió otorgarles un lugar más relevante a aquellos cuyo combate parecía ucrónico. Su remembranza quedaba equiparada a un mito del pasado del que había que liberarse.

Trascurrido el tiempo, algunas películas, junto a obras literarias y ensayos, han contribuido a devolver al maquis el espacio que les corresponde. La sociedad civil se ha ocupado de dar el protagonismo que merecen estos luchadores de una guerra in- 
acabada, cuyas acciones provocan a la vez un rechazo racional y un respeto emocional. Su tenacidad no fue en vano, aunque perdieron la batalla política y militar, la razón moral del vencido se ha dejado sentir durante mucho tiempo en nuestra sociedad. 